\title{
Natural decomposition of hornbeam wood decayed by the white rot fungus Trametes versicolor
}

\author{
MARYAM KARIM ${ }^{1}$, MEHRDAD GHODSKHAH DARYAEI ${ }^{1}$, JAVAD TORKAMAN ${ }^{1}$, REZA \\ OLADI $^{2}$, MOHAMMAD ALI TAJICK GHANBARY ${ }^{3}$, EHSAN BARI ${ }^{4,5}$ and NURAL YILGOR ${ }^{6}$ \\ ${ }^{1}$ Department of Forestry, Faculty of Natural Resources, University of Guilan, 43619-96196 Guilan, Iran \\ ${ }^{2}$ Department of Wood Science and Technology, Faculty of Natural Resources, University of Tehran, 31585-4314 Karaj, Iran \\ ${ }^{3}$ Department of Mycology and Plant Pathology College of Agronomic Sciences, \\ Agriculture and Natural Resources University, 48181-68984 Sari, Iran \\ ${ }^{4}$ Department of Wood Science and Engineering, Technical Faculty of Sari No 2, 48157-33944 Sari, Iran \\ ${ }^{5}$ Department of Wood and Paper Science, Sari Agriculture Science and Natural Resources University, Sari, Iran \\ ${ }^{6}$ Department of Forest Products Chemistry and Technology Division, Forest Industry \\ Engineering, Forestry Faculty, Istanbul University, 34473 Istanbul, Turkey
}

Manuscript received on October 17, 2016; accepted for publication on November 28, 2016

\begin{abstract}
The impacts of white-rot fungi on altering wood chemistry have been studied mostly in vitro. However, in vivo approaches may enable better assessment of the nature of interactions between saprotrophic fungi and host tree in nature. Hence, decayed and sound wood samples were collected from a naturally infected tree (Carpinus betulus L.). Fruiting bodies of the white rot fungus Trametes versicolor grown on the same tree were identified using rDNA ITS sequencing. Chemical compositions (cellulose and lignin) of both sound and infected wood were studied. FT-IR spectroscopy was used to collect spectra of decayed and un-decayed wood samples. The results of chemical compositions indicated that $T$. versicolor reduced cellulose and lignin in similar quantities. Fungal activities in decayed wood causes serious decline in $\mathrm{pH}$ content. The amount of alcohol-benzene soluble extractives was severely decreased, while a remarkable increase was found in $1 \%$ sodium hydroxide soluble and hot water extractive contents in the decayed wood samples, respectively. FT-IR analyses demonstrated that $T$. versicolor causes simultaneous white rot in the hornbeam tree in vivo which is in line with in vitro experiments.
\end{abstract}

Key words: Hornbeam wood, Trametes versicolor, chemical compositions, FT-IR analyses.

\section{INTRODUCTION}

Major decay process caused by fungi initially starts through wounds and cracks in the stem branches and roots of living trees. Later, when tree dies, other fungi gain access to the woody material and

Correspondence to: Maryam Karim

E-mail: maryam.karim88@gmail.com immediately speed up the decomposition process (Stokland et al. 2012, Schwarze et al. 2004, Schmidt 2006). Several microorganisms may be involved in the degradation. The most efficient wood destroyers are the white-rot and brown-rot fungi among the Basidiomycetes (Eriksson et al. 1990, Eaton and Hale 1993, Schmidt 2006). In addition, some Ascomycetes and Deuteromycetes cause a 
different type of wood rot called soft rot. However, some white rot fungi are able to decompose wood in a similar way to soft rot decay (Schwarze et al. 2004, Bari et al. 2017).

The majority of the white-rot fungi use cellulose and hemicelluloses at nearly the same rate; however, lignin is usually utilized at a somewhat faster rate. A few white-rot fungi, on the other hand, remove lignin and hemicelluloses preferentially, but eventually degrade all wood cell wall components. These fungi invade tissues of hardwoods and they rarely have been seen on softwoods (Schmidt 2006, Kubicek 2013). White rot has been classified by macroscopic characteristics into simultaneous and selective white rot and (Schmidt 2006, Kubicek 2013). Many white-rot fungi seem to produce just one of these behaviors, but some species can cause alternative forms under different conditions (Martínez et al. 2005, Bari et al. 2015c). Many white-rot fungi occur as dormant spores within the live sapwood and immediately after falling moisture content in dead cells, the mycelium grows and the decomposition starts (Boddy 1994).

The impacts of white-rot fungi on wood chemistry have been studied by various methods (e.g. Martínez et al. 2001, Mohebby 2005, Bari et al. 2015a, Karim et al. 2016) But the most of the above mentioned methods have been carried out in vitro. However, there are inherent difficulties in emulating micro-environmental conditions occurring in the field (Rayner and Webber 1984) and in vivo approaches may enable better assessment of the nature of interactions between saprotrophic fungi and the wood (Woodward and Boddy 2008). In this regards, the white-rot fungus Trametes versicolor is a unique microorganisms that has a widespread host (Eaton and Hale 1993, Schmidt 2006) and act as great carbon recycler in the natural forest ecosystems. Hornbeam (Carpinus betulus) is an important tree species in Iran, economically and ecologically which accounts for $30.5 \%$ of the standing volume and $30 \%$ of the stem number in the Hyrcanian forests of Iran. This species in combination with beech compose 54 and $60 \%$ of the stem number and standing volume of the Iranian Northern Forests, respectively (Sagheb Talebi et al. 2014), and therefore, it has been studied from different aspects (Taghiyari and Sarvari Samadi 2010).

More than $90 \%$ of wood decaying fungi in standing and felled trees in the north of Iran and America are caused by white-rotting fungi (Gilbertson 1980, Bari et al. 2015a). Thus, the white rot fungi called as predator and terminator for natural forest ecosystems (Bari et al. 2016) and many studies were carried out on them (Taghiyari et al. 2015). Former studies (Bari et al. 2015a, b, $\mathrm{c}, \mathrm{d}, 2016)$ demonstrated that the white-rot fungus Trametes versicolor produces simultaneous decay in beech wood in laboratory condition (in vitro) (Bari et al. 2016). In this respect, a question arises that whether the degradation patterns of hornbeam wood decayed by this fungus is the same as in beech or not? In addition, will the fungus produce simultaneous or selective decay? The naturally decomposition of wood gives us new and significant knowledge about the behavior of fungi in nature compared to controlled conditions. Moreover, investigations of decomposition processes in forest ecosystems will be useful from the natural recycling of organic substance point of views (Stokland et al. 2012). Since there is no information about the behavior of this fungus in natural conditions, this study is aimed to assess the chemical composition of wood naturally decayed by $T$. versicolor. FT-IR spectroscopic analysis was accompanied with conventional chemical analysis to study the chemical changes in hornbeam wood attacked by the white-rot fungus $T$. versicolor. Comparable studies had been already done with the same fungus and Fagus orientalis wood (Bari et al. 2015a). 


\section{MATERIALS AND METHODS}

\section{FUNGI IDENTIFICATION}

The fruiting bodies of white rot fungus Trametes versicolor (L.: Fr.) Pilát were collected from a fallen hornbeam tree (Carpinus betulus L.) at the Guilan forest, northwest Iran. Then morphology identification was done according to Ryvarden and Gilbertson $(1993,1994)$ and molecular identification was carried out according to Schmidt et al. (2012) and Bari (2014) with ten replicates. In brief, the DNA of the infected wood and fruiting bodies of fungi were extracted; PCR was amplified with primers ITS1 and ITS4, electrophoresed, purified, and sequenced. Thereafter, the identification was accomplished by the sequence comparison with sequences deposited in the DNA databases using the BLAST in the NCBI. The same tree was used for further chemical analyses (see below).

\section{CHEMICAL ANALYSIS}

Un-decayed and parts of the naturally decayed wood specimen were cut, dried at $103 \pm 2{ }^{\circ} \mathrm{C}$ for 24 hours, and then ground to pass a 40-mesh (420$\mu \mathrm{m})$ screen. The preparation of the wood powder for chemical composition analysis was done according to TAPPI standard (T 264 om-88, 1988). Lignin and cellulose content of both kinds of wood samples were measured using T 222 om-98 (1998), and T 17 wd-97 (1997a) procedures, respectively. The chemical percent of wood extractives was evaluated in accordance with TAPPI T 212 om-93 (1993a), TAPPI T 207 om-93 (1993b), and TAPPI T 204 cm-97 (1997b) standard methods, respectively. The $\mathrm{pH}$ values of the samples were calculated using a $\mathrm{pH}$ meter device. For this purpose, about 1 grams of meshed wood powder was added to $25 \mathrm{ml}$ distilled water and they were kept in room condition overnight. Then, the $\mathrm{pH}$ meter was calibrated with distilled water and $\mathrm{pH}$ values of the samples were then determined. All analyses were done with five replicates.

\section{FT-IR SPECTROSCOPY}

Dried samples were milled and passed through a mesh 40 sieve mesh. FT-IR spectra were obtained directly from wood powder. Using a Shimadzu 8400s FT-IR Spectrometer equipped with DLATGS detector, all samples were examined at a spectral resolution of $4 \mathrm{~cm}^{-1}$ : Spectra from 30 scans of sample and background scans were measured. The background spectra were collected using an empty collector. A rubber band method was used for baseline correction. The band for $\mathrm{CO}_{2}$ was removed to make a suitable baseline correction (Mohebby 2005).

\section{STATISTICAL ANALYSIS}

To compare chemical losses, a Student t-test was performed (95\% confidence level) between decayed and un-decayed samples. Statistical analysis was performed using the SPSS software program, version 17 (2010).

\section{RESULTS AND DISCUSSION}

\section{FUNGI IDENTIFICATION}

The results indicated that three fungi i.e. Trametes versicolor, Trichoderma harzianum (Rifai.) and Mortierella elongata (Linnem.) were present in the samples, while $T$. versicolor was the only found white-rot fungus. On the other hand, T. harzianum and M. elongate as members of the Pezizomycetes and Mucoromycetes might have participated in the decomposition of wooden disc. T. harzianum is known as a mycoparasite and a cellulolytic fungus, while M. elongata is a terrestrial saprophytic fungus inhabiting soil that may use sugar material from wood or other plants (Eaton and Hale 1993). 


\section{CHEMICAL ANALYSIS}

The average chemical components in un-decayed and naturally-decayed hornbeam samples by $T$. versicolor are shown in Table I. As depicted in this figure, mean cellulose loss was a bit more pronounced compared to lignin degradation. On the other hand, at the examined stage of decay, cellulose and lignin were degraded approximately at the same rate. T. versicolor contains the full lingocellulosic enzyme system for degrading all wood cell walls layers. Entire decomposition of wood cell walls by fungi will take place only when the fungi have all necessary enzymes for degradation. In this regard, only some wood decaying fungi such as Phanerochaete chrysosporium, P. carnosa and $T$. versicolor have the full genome for degradation (Canam et al. 2013). However, fungi which are specialized may have different behavior in nature than under controlled conditions. There are also evidences that certain cell wall components may induce the production of the necessary enzymes. Thus cellulose induces the formation of carbohydrolases in white-rotting fungi (Fengel and Wegener 1989). Nonetheless, since T. versicolor is a member of the white-rot fungi, these behaviors were expected. Several literatures (e.g. Eriksson et al. 1990) as well as our former studies (Bari et al. 2015a, c) in controlled situation, demonstrated the simultaneous decay behavior of this fungi. The average losses of cellulose and lignin were $32.52 \%$ and $26.10 \%$, respectively which were in accordance with former studies and our investigations on Fagus orientalis wood (Bari et al. 2015a). A significant decrease was seen in $\mathrm{pH}$ value in naturally decayed wood. According to Humar et al. (2001), the fungi are able to severely reduce the $\mathrm{pH}$ in wood after advancement of decay. Nonetheless, it has been known that white-rot fungi do not cause such massive decline in $\mathrm{pH}$ of wood comparing to brown-rot fungi (Shortle 1990). On the other hand, considerable changes were recorded in extractives constituent values of decayed wood. Reduction of alcohol-benzene soluble extractives was observed in decayed samples. However, $1 \% \mathrm{NaOH}$ soluble extractives as well as hot-water soluble extractives were increased in decayed wood samples. It was found that the wood decaying fungi hydrolyze the extractives such as styrel esters and waxes into fatty acid and sterol moieties as an important source of carbon for the their growth (Silk et al. 2001). In this regards, similar observations (e.g. Malakani et al. 2014) were reported.

\section{FT-IR EVALUATIONS UNDECAYED WOOD (CONTROL)}

The FT-IR spectrum of un-decayed hornbeam wood is depicted in Figure 1. A strong hydrogen bonded $(\mathrm{O}-\mathrm{H})$ stretching absorption was observed at $3500-3300 \mathrm{~cm}^{-1}$ (1) and a prominent $\mathrm{C}-\mathrm{H}$ stretching absorption around $2896 \mathrm{~cm}^{-1}$ (2). On top of that, there were many well-defined peaks in the fingerprint region between $1800-500 \mathrm{~cm}^{-1}$. The peaks in the fingerprint were assigned in accordance with several studies (e.g. Harrington et al. 1964, Hergert 1971, Schultz and Glasser 1986, Faix 1992, Pandey and Pitman 2003, Mohebby 2005), the assigned peaks in the above mentioned literatures were un-conjugated at $1738 \mathrm{~cm}^{-1}$ (3); conjugated $\mathrm{C}-\mathrm{O}$ stretching at $1594 \mathrm{~cm}^{-1}$ (4); aromatic skeletal vibration at $1504 \mathrm{~cm}^{-1}$ (5); $\mathrm{C}-\mathrm{H}$ deformation in lignin and carbohydrates at wave numbers 1461 (6) and $1423 \mathrm{~cm}^{-1}$ (7); C-H deformation in cellulose and hemicelluloses at $1372 \mathrm{~cm}^{-1}$ (8); C-H vibration in cellulose and $\mathrm{C}_{1}-\mathrm{O}$ vibration in syringyl derivatives at $1325 \mathrm{~cm}^{-1}$ (9); syringyl ring and $\mathrm{C}-\mathrm{O}$ stretching in lignin and xylan at wave number $1238 \mathrm{~cm}^{-1}$ (10); $\mathrm{C}-\mathrm{O}-\mathrm{C}$ vibration in cellulose and hemicellulose at $1157 \mathrm{~cm}^{-1}$ (11); aromatic skeletal and $\mathrm{C}-\mathrm{O}$ stretch at $1096 \mathrm{~cm}^{-1}$ (12); $\mathrm{C}-\mathrm{O}$ stretch in cellulose and hemicelluloses at wave number 1035 $\mathrm{cm}^{-1}$ (13) and C-H deformation in cellulose at 892 $\mathrm{cm}^{-1}(14)$. 
TABLE I

Average of percent chemical components in decayed hornbeam wood in sound and naturally infected sample by white-rot fungus Trametes versicolor.

\begin{tabular}{lcc}
\hline \multirow{2}{*}{ Wood Property } & \multicolumn{2}{c}{ Exposure condition } \\
\cline { 2 - 3 } & Un-decayed & Naturally decayed \\
\hline Lignin & $31.77 \pm 2.83$ & $26.10 \pm 1.66$ \\
Cellulose & $42.52 \pm 1.39$ & $32.52 \pm 1.81$ \\
$\mathrm{pH}$ & $05.31 \pm 0.55$ & $03.26 \pm 0.41$ \\
Alcohol-benzene soluble extractives (\%) & $02.71 \pm 0.84$ & $01.98 \pm 1.02$ \\
Hot-water soluble extractives (\%) & $05.12 \pm 1.36$ & $06.48 \pm 1.73$ \\
$1 \% \mathrm{NaOH}$ soluble extractives (\%) & $21.36 \pm 2.04$ & $32.51 \pm 2.65$ \\
\hline
\end{tabular}

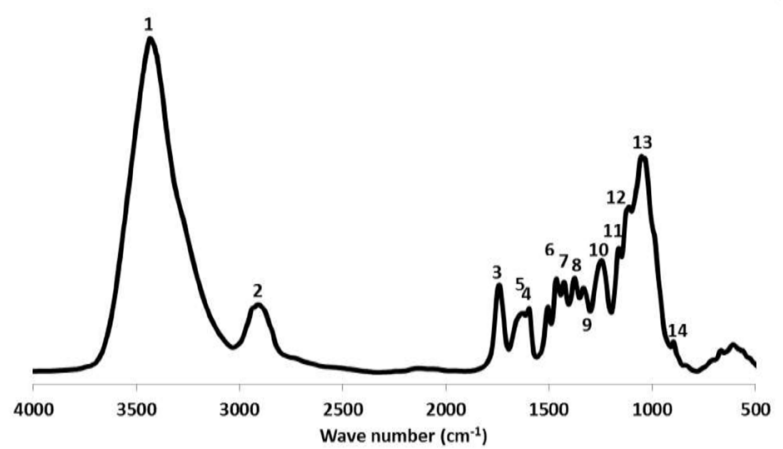

Figure 1 - FT-IR spectrum bands of un-decayed Carpinus betulus.

\section{FT-IR SPECTRA OF DECAYED WOOD}

The result of FT-IR spectra analyses of decayed and un-decayed wood is summarized in Table II. The FT-IR spectra of decayed hornbeam wood (Fig. 2) demonstrated changes of peaks in fingerprint regions at the naturally infected wood by $T$. versicolor. The comparison between the peaks from the decayed and un-decayed wood revealed that some peaks had severe changes; thus the subtraction of peaks demonstrated that amounts of abortion in the most picks were slightly increased in the fingerprint region. In Fig. 3 the baselines shows high differences between the un-decayed and the decayed wood; while the peaks under the baselines showed an increase of bands and above the baselines indicated prominent declined of the bands.

The FT-IR spectra of decayed and un-decayed hornbeam wood (Fig. 1) demonstrated changes of the peaks in fingerprint regions of wood decayed by $T$. versicolor. There were many well-defined peaks in the fingerprint region of $1800-500$ $\mathrm{cm}^{-1}$. A severe decline took place at $1738 \mathrm{~cm}^{-1}$ which caused heavily reduction belonging to unconjugated groups in lignin and carboxylic acid ester hemicelluloses (Takahashi et al. 1989), This behavior was expected for this fungus; because white rot fungi use all three major chemical compositions in the cell wood wall (Eriksson et al. 1990, Eaton and Hale 1993, Schmidt 2006, Kubicek 2013), as a result of fungal activities, a considerable increase at $1594 \mathrm{~cm}^{-1}$ peak was seen which is related to carbon-oxygen bond (Pandey and Pitman 2003), a carbon-oxygen bond is a covalent bond between carbon and oxygen (Carey and Sundberg 2007), which was increased after the attack by white rot fungi (Fengel and Wegener 1989). Microbial cellulolysis is a very complex procedure, especially in view of that portion of the mechanism that relates to the degradation of hydrogen bond-ordered cellulose (Wood and Garcia-Campayo 1994). Therefore, cellulolysis by white-rot fungi involves the interaction of enzymes defined as exoglucanases and endoglucanases as well as B-glucosidases (Eriksson and Wood 1985). Carbon and oxygen form terminal double bonds in functional groups are collectively known as carbonyl compounds to which belong such compounds as ketones, esters, carboxylic acids and many more. Compounds with formal $\mathrm{C}-\mathrm{O}$ triple 
TABLE II

The molecular chemical composition changes in hornbeam wood in sound and naturally infected sample by white-rot fungus Trametes versicolor.

\begin{tabular}{|c|c|c|c|}
\hline \multirow[b]{2}{*}{ Peaks } & \multirow[b]{2}{*}{ Properties } & \multicolumn{2}{|c|}{ Status } \\
\hline & & Increase & Decrease \\
\hline 1738 & $\begin{array}{c}\mathrm{C}=\mathrm{O} \text { un-conjugated } \\
\text { groups in lignin and } \\
\text { carboxylic acid ester } \\
\text { hemicelluloses }\end{array}$ & & + \\
\hline 1594 & Conjugated $\mathrm{C}-\mathrm{O}$ & + & \\
\hline 1504 & $\begin{array}{c}\text { Aromatic skeletal; } \\
\text { Benzene ring vibration } \\
\text { in lignin }\end{array}$ & & + \\
\hline \multirow{2}{*}{1461} & $\begin{array}{l}\mathrm{C}-\mathrm{H} \text { deformation in } \\
\text { lignin and carbohydrates }\end{array}$ & & + \\
\hline & $\begin{array}{l}\mathrm{CH}_{3}, \mathrm{CH}_{2} \text {, benzene ring } \\
\text { vibration in lignin }\end{array}$ & & \\
\hline \multirow[b]{2}{*}{1423} & $\begin{array}{l}\mathrm{C}-\mathrm{H} \text { deformation in } \\
\text { lignin and carbohydrates }\end{array}$ & & + \\
\hline & $\begin{array}{c}\text { Aromatic skeletal } \\
\text { vibrations combined } \\
\text { with C-H in plane } \\
\text { deformation } \\
\end{array}$ & & \\
\hline \multirow{2}{*}{1372} & $\begin{array}{l}\text { C-H deformation } \\
\text { in cellulose and } \\
\text { hemicelluloses }\end{array}$ & & + \\
\hline & $\begin{array}{l}\mathrm{C}-\mathrm{H} \text { bending vibration } \\
\text { in cellulose and } \\
\text { hemicelluloses }\end{array}$ & & \\
\hline 1325 & $\begin{array}{l}\mathrm{C}-\mathrm{H} \text { vibration in } \\
\text { cellulose; } \mathrm{C}_{1}-\mathrm{O} \text { in } \\
\text { syringyl derivatives }\end{array}$ & & + \\
\hline 1238 & $\begin{array}{l}\text { Syringyl ring; } \mathrm{C}-\mathrm{O} \\
\text { stretch in lignin and } \\
\text { xylan }\end{array}$ & & + \\
\hline 1157 & $\begin{array}{l}\mathrm{C}-\mathrm{O}-\mathrm{C} \text { vibration } \\
\text { in cellulose and } \\
\text { hemicelluloses }\end{array}$ & & + \\
\hline \multirow[b]{2}{*}{1096} & $\begin{array}{c}\text { Aromatic skeletal; } \mathrm{C}-\mathrm{C} \\
\text { stretch }\end{array}$ & & + \\
\hline & $\begin{array}{c}\mathrm{O}-\mathrm{H} \text { association } \\
\text { band in cellulose and } \\
\text { hemicelluloses }\end{array}$ & & \\
\hline \multirow{2}{*}{1035} & $\begin{array}{l}\mathrm{C}-\mathrm{O} \text { stretch in cellulose } \\
\text { and hemicelluloses }\end{array}$ & & + \\
\hline & $\mathrm{C}-\mathrm{O}$ of primary alcohol & & \\
\hline \multirow[b]{2}{*}{892} & $\begin{array}{l}\mathrm{C}-\mathrm{H} \text { deformation in } \\
\text { cellulose }\end{array}$ & & + \\
\hline & $\begin{array}{c}\mathrm{C}_{1} \text { group frequency } \\
\text { in cellulose and } \\
\text { hemicellulose }\end{array}$ & & \\
\hline
\end{tabular}

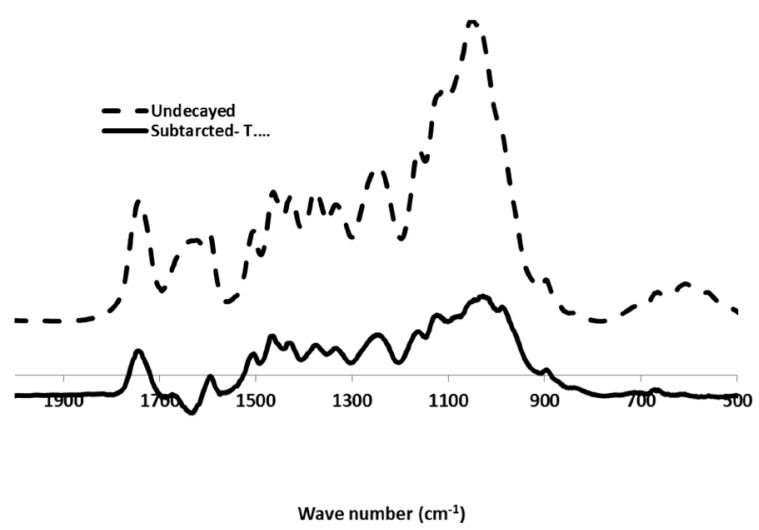

Figure 2 - Subtracted FT-IR spectra of the white-rot decayed hornbeam wood in naturally infected (in vivo) by Trametes versicolor.

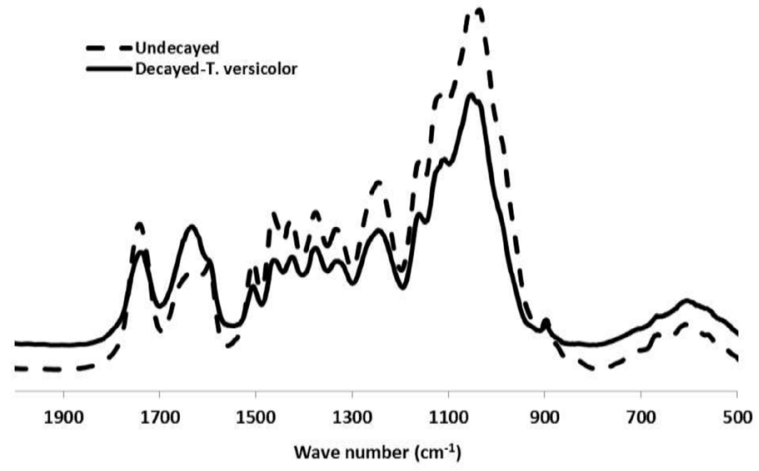

Figure 3 - FT-IR spectra of hornbeam wood naturally infected by Trametes versicolor (in vivo).

bonds do not exist except for carbon monoxide, which has a very short, strong bond (reported from the standard bond energies). The wood-inhabiting microorganisms use carbon only from enzymatically easily accessible and digestible substrates, like simply constructed sugars, peptides, or fats, or from the storage material starch in the parenchyma cells. The wood decay fungi use carbon additionally from the complex, main components of the woody cell wall, cellulose, hemicelluloses, and lignin (Fengel and Wegener 1989, Schmidt 2006, Kubicek 2013) decreases in intensity observed at around 1504; $1461 ; 1423 ; 1372 ; 1325 ; 1238 ; 1157 ; 1096 \mathrm{~cm}^{-1}$ were related to aromatic skeletal; benzene ring vibration in lignin, deformation in lignin and carbohydrates as well as benzene ring vibration 
in lignin; aromatic skeletal vibrations combined with $\mathrm{C}-\mathrm{H}$ in plane deformation, deformation in cellulose and hemicelluloses and bending vibration in cellulose and hemicelluloses, vibration in cellulose, $\mathrm{C}_{1}-\mathrm{O}$ in syringyl derivatives, syringyl ring $\mathrm{C}-\mathrm{O}$ stretch in lignin and xylan, vibration in cellulose and hemicelluloses, aromatic skeletal and $\mathrm{C}-\mathrm{C}$ stretch and association band in cellulose and hemicelluloses, respectively. This condition of attack by white-rot fungi has been reported in several studies (Pandey and Pitman 2003, Faix et al. 1993, Mohebby 2005, Yilgor et al. 2013, Bari et al. 2015a). Different types of hydrolyzing enzyme could be liberated to alter and break linkages in the cell-wall components and release them as small molecules. During this period, many chemical changes occur in these constituents, indicating that the fungus could assimilate them as carbon sources. A strong decrease took place in the carbon-oxygen bonds which was seen at the $1035 \mathrm{~cm}^{-1}$ bond that demonstrated a decrease in primary alcohol. Moreover, a slight decline was observed at 892 $\mathrm{cm}^{-1}$ which belongs to the deformation in cellulose as well as $\mathrm{C}_{1}$ group frequency in cellulose and hemicellulose (Mohebby 2005, Bari et al. 2015a).

\section{CONCLUSIONS}

The white-rot fungus Trametes versicolor caused similar chemical components losses in the xylem of hornbeam wood samples at the advanced decay stages in vivo. FT-IR spectroscopy along with chemical analyses evaluated the qualitative and quantitative changes in lignin and carbohydrate components of infected wood by this fungus. The results showed that $T$. versicolor reduced lignin and carbohydrate nearly at the same rate, with a slight preference for lignin which was reflected in a small reduction in the lignin/carbohydrate peak area ratio as decay progressed. Nonetheless, T. versicolor had the ability to degrade all three cell wall polymers. Overall, this study proved that this fungus induce simultaneous white rot decay in hornbeam wood in natural situation (in vivo).

\section{ACKNOWLEDGMENTS}

Thanks are to Dr. Nadre Bahramifar University of Tarbiat Modares for cooperation in preparation samples for FT-IR analyses and Mrs. Hakimeh Ziaie Juibari, Sari Agriculture and Natural Resources University for collaboration in preparation samples of fungal for DNA extraction.

\section{REFERENCES}

BARI E. 2014. Potential of biological degradation of oriental beech wood by the white-rot fungus Pleurotus ostreatus and the effects on mechanical and chemical properties there of and its comparison with standard the white-rot fungus Trametes versicolor. Master Thesis, Sari Agriculture and Natural Resources University, Sari, Iran. (Unpublished).

BARI E, KARIM M, OLADI R, TAJICK GHANBARY MA, GHODSKHAH DARYAEI M, SCHMIDT O, BENZ JP AND EMAMINASAB M. 2017. A comparison between decay patterns of the white-rot fungus Pleurotus ostreatus in chestnut-leaved oak (Quercus castaneifolia) shows predominantly simultaneous attack both in vivo and in vitro. For Path http://onlinelibrary.wiley.com/ doi/10.1111/efp.12338/abstract

BARI E, NAZARNEZHAD N, KAZEMI SM, TAJICK GHANBARY MA, MOHEBBY B, SCHMIDT O AND CLAUSEN CA. 2015a. Comparison of degradation capabilities of the white rot fungi Pleurotus ostreatus and Trametes versicolor. Int Biodeterior Biodegr 104: 231 237.

BARI E, OLADI R, SCHMIDT O, CLAUSEN CA, OHNO K, NICHOLAS DD, GHODSKHAH DARYAEI M AND KARIM M. 2015b. Influence of xylem ray integrity and degree of polymerization on bending strength of beech wood decayed by Pleurotus ostreatus and Trametes versicolor. Int Biodeterior Biodegr 104: 299-306.

BARI E, SCHMIDT O AND OLADI R. 2015c. A histological investigation of Oriental beech wood decayed by Pleurotus ostreatus and Trametes versicolor. For Path 45: 349-357.

BARI E, TAGHIYARI HR, MOHEBBY B, CLAUSEN CA, SCHMIDT O AND VASEGHI MJ. 2015d. Mechanical properties and chemical composition of beech wood exposed for 30 and 120 days to white-rot fungi. Holzforschung 69: 587-593.

BARI E, TAGHIYARI HR, NAJI HR, SCHMIDT O, OHNO MK, CLAUSEN CA AND BAKAR ES. 2016. Assessing the destructive behavior of two white-rot 
fungi on beech wood. Int Biodeterior Biodegr 114: 129140.

BODDY L. 1994. Latent decay fungi: the hidden foe? Arboric J 18: 113-135.

CANAM T, TOWN J, IROBA K, TABIL L AND DUMONCEAUX T. 2013. Pretreatment of lignocellulosic biomass using microorganisms: approaches, advantages, and limitations. In: Chandel AK and Silva SS (Eds), Sustainable degradation of lignocellulosic biomasstechniques, applications and commercialization, p. 181206.

CAREY FA AND SUNDBERG RJ. 2007. Advanced Organic Chemistry, $5^{\text {th }}$ ed., Springer-Verlag, Berlin, New York.

EATON RA AND HALE MDC. 1993. Wood: decay, pests and protection. Chapman and Hall, London.

ERIKSSON KEL, BLANCHETTE RA AND ANDER P. 1990. Microbial and enzymatic degradation of wood and wood components. Springer, Berlin.

ERIKSSON KEL AND WOOD TM. 1985. Biodegradation of cellulose. In: Higuchi $\mathrm{T}(\mathrm{Ed})$, Biosynthesis and Biodegradation of Wood Components. Academic Press, London, p. 469-504.

FAIX O. 1992. Fourier transform infrared spectroscopy. In: Lin SY AND Dence CW (Eds), Methods in Lignin Chemistry. Springer, Berlin, p. 83-109.

FAIX O, BREMER J, SCHMIDT O AND STEVANOVIC T. 1993. Monitoring of chemical changes in white-rot degraded beech wood by pyrolysis gas chromatography and Fourier transform infrared spectroscopy. J Anal Appli Pyrol 21: 147-162.

FENGEL D AND WEGENER G. 1989. Wood: Chemistry, ultrastructure, reactions, $2^{\text {nd }}$ ed., de Gruyter, Berlin.

GILBERTSON RL. 1980. Wood-rotting fungi of North America. Mycologia 72: 1-49.

HARRINGTON KJ, HIGGINS HG AND MICHELL AJ. 1964. Infrared spectra of Eucalypus regnans F. Muell. and Pinus radiata D. Don. Holzforschung 18: 108-113.

HERGERT HL. 1971. Infrared spectra. In: Sarkanen KV and Ludwig CH (Eds), Lignins: Occurrence, Formation, Structure and Reactions. Wiley Interscience, New York, p. 267-297.

HUMAR M, PETRIC M, POHLEVEN F. 2001. Changes of the $\mathrm{pH}$ value of impregnated wood during exposure to wood rotting fungi. Holz Roh Werkst 59: 288-293.

KARIM M, GHODSKHAH DARYAEI M, TORKAMAN J, OLADI R, TAJICK GHANBARY MA AND BARI E. 2016. In vivo investigation of chemical alteration in Oak wood decayed by Pleurotus ostreatus. Int Biodeterior Biodegr 108: 127-132.

KUBICEK CP. 2013. Fungi and lignocellulosic biomass. Chichester: John Wiley \& Sons, Inc.

MALAKANI M, KHADEMIESLAM H, HOSSEINI HASHEMI SK AND ZEINALY F. 2014. Influence of fungal decay on chemi-mechanical properties of beech wood (Fagus orientalis). Cellulose Chem Technol 48: 97103.

MARTÍNEZ AT, CAMARERO S, GUTIÉRREZ A, BOCHINI P AND GALLETI GC. 2001. Studies on wheat lignin degradation by Pleurotus species using analytical pyrolysis. J Anal Appli Pyrol (58-59): 401-411.

MARTÍNEZ AT, SPERANZA M, RUIZ-DUEÑAS FJ, FERREIRA P, CAMARERO S, GUILLÉN F, MARTÍNEZ MJ, GUTIÉRREZ A AND DELRÍO JC. 2005. Biodegradation of lignocellulosics: microbial, chemical, and enzymatic aspects of the fungal attack of lignin. Intern Microbiol 8: 195-204.

MOHEBBY B. 2005. Attenuated total reflection infrared spectroscopy of white-rot decayed beech wood. Int Biodeterior Biodegr 55: 247-251.

PANDEY KK AND PITMAN AJ. 2003. FTIR studies of the changes in wood following decay by brown-rot and whiterot fungi. Int Biodeterior Biodegr 52: 151-160.

RAYNER ADM AND WEBBER JF. 1984. Interspecific mycelial interactions - An overview. In: Jennings DH and Rayner ADM (Eds), The Ecology and Physiology of the Fungal Mycelium. Cambridge University Press, Cambridge, UK, p. 383-417.

RYVARDEN L AND GILBERTSON RL. 1993. European Polypores: Volumes 1-2. Oslo: Fungiflora.

RYVARDEN L AND GILBERTSON RL. 1994. European Polypores: Volumes 2. Oslo: Fungiflora.

SAGHEB TALEBI K, SAJEDI T AND POURHASHEMI M. 2014. Forests of Iran: A Treasure from the Past, a Hope for the Future Plant and Vegetation, Vol 10. Springer, Netherlands.

SCHMIDT O. 2006. Wood and Tree Fungi: Biology, Damage, Protection, and Use. Springer, Berlin, Heidelberg.

SCHMIDT O, GAISER O AND DUJESIEFKEN D. 2012. Molecular identification of decay fungi in the wood of urban trees. Eur J For Res 131: 885-891.

SCHULTZ TP AND GLASSER WG. 1986. Quantitative structural analysis of lignin by diffuse reflectance fourier transform spectrometry. Holzforschung 40: 37-44.

SCHWARZE FWMR, ENGELS J AND MATTHEK C. 2004. Fungal strategies of wood decay in trees. $2^{\text {nd }}$ ed., Springer, Berlin, Heidelberg, New York.

SHORTLE WC. 1990. Ionization of wood during previsual stages of wood decay. In: Llewellyn GC and O'Rear CE (Eds), Biodeterioration Research, Vol 3: mycotoxins, biotoxins, wood decay, air quality, cultural properties, general biodeterioration, and degradation. Springer Science + Business Media New York, p. 333-348.

SILK PJ, AUBRY C, LONERGAN GC AND MACAULAY JB. 2001. Chlorometabolite production by the ecologically important white rot fungus. Chemosphere 44: 7. 
STOKLAND JN, SIITONEN J AND JONSSON BG. 2012. Biodiversity in dead wood. Cambridge University Press.

TAGHIYARI HR, KALANTARI A, GHORBANI M, BAVANEGHI F AND AKHTARI M. 2015. Effects of fungal exposure on air and liquid permeability of nanosilver-and nanozincoxide impregnated Paulownia wood. Int Biodeterior Biodegr 105: 51-57.

TAGHIYARI HR AND SARVARI SAMADI Y. 2010. Ultimate length for reporting gas permeability of Carpinus betulus wood. Special Topics \& Reviews in Porous Media - An International Journal 1(4): 345-351.

TAKAHASHI M, IMAMURA Y AND TANAHASHI M. 1989. Effect of acetylation on decay resistance of wood against brown rot, white rot and soft rot. International Chemistry, Congress of Pacific Basin Societies, Agrochemistry, Sub-symposium on Chemical Modification of lignocellulosic Materials-Chemical Reactions, $16 \mathrm{p}$.

TAPPI STANDARD. 1988. Preparation of wood for chemical analysis, T 264 om- 88.

TAPPI STANDARD. 1993a. One percent sodium hydroxide solubility of wood and pulp, T 212 om-93.
TAPPI STANDARD. 1993b. Water solubility of wood and pulp, T 207 om-93.

TAPPI STANDARD. 1998. Standard methods for acidinsoluble lignin in wood and pulp, T 222. om-98.

TAPPI STANDARD. 1997a. Cellulose in wood, T 17 wd-97.

TAPPI STANDARD. 1997b. Wood extractives in ethanolbenzene mixture, T $204 \mathrm{~cm}-97$.

WOOD TM AND GARCIA-CAMPAYO V. 1994. Enzymes and mechanisms involved in microbial cellulolysis. In: Ratledge C (Ed), Biochemistry of microbial degradation. Springer Science + Business Media, B.V., p. 197-231.

WOODWARD S AND BODDY L. 2008. Interactions between saprotrophic fungi. In: Boddy L, Frankland JC and Van West P (Eds), Ecology of saprotrophic Basidiomycetes, Academic Press, Elsevier, p. 125-141.

YILGOR N, DOGU D, MOORE R, TERZI E AND KARTAL SN. 2013. Evaluation of fungal deterioration in Liquidambar orientalis Mill. heartwood by FT-IR and light microscopy. BioResources 8: 2805-2826. 